Jurnal Pendidikan Dasar PerKhasa

Volume 4, Nomor 2, Oktober 2018

\title{
PEMBELAJARAN BERORIENTASI TAXONOMY FOR SCIENCE EDUCATION UNTUK MENINGKATKAN SIKAP ILMIAH SISWA SEKOLAH DASAR
}

\author{
Imanuel Sairo Awang \\ Program Studi PGSD, STKIP Persada Khatulistiwa Sintang \\ email: iman.saiaw@gmail.com
}

\begin{abstract}
The aim of the research is to know the improvement of students' scientific attitude after using Taxonomy For Science Education-oriented learning. This is a classroom action research with the subject of the research is the fourth grade students of SD Negeri 5 Sintang. The Data collection tool is a scientific attitude questionnaire with students' scientific attitude on natural sciences subject . based on data analisys, it can be concluded that, the Taxonomy For Science Education oriented learning can improve students' scientific attitude.
\end{abstract}

Keywords: Taxonomy For Science Education, scientific attitude

Abstrak: Penelitian bertujuan untuk mengetahui peningkatan sikap ilmiah siswa setelah menggunakan pembelajaran berorientasi Taxonomy For Science Education. Bentuk Penelitian ini adalah penelitian tindakan kelas dengan subjek penelitian adalah siswa kelas IV SD Negeri 5 Sintang. Alat Pengumpulan data adalah angket sikap ilmiah, dengan data yang dihasilkan adalah data sikap ilmiah pada mata pelajaran ilmu pengetahuan alam. Berdasarkan hasil analisis, dapat disimpulkan bahwa, pembelajaran berorientasi Taxonomy For Science Education dapat meningkatkan sikap ilmiah siswa.

Kata kunci: Taxonomy For Science Education, sikap ilmiah

\section{Pendahuluan}

Pendidikan merupakan suatu
proses yang sangat penting dalam
rangka menyiapkan anak-anak
menghadapi kehidupannya di masa
mendatang. Kristin (Prihatiningsih, 2018:

2) menjelaskan bahwa pendidikan merupakan hal yang penting dalam kehidupan manusia dan manusia mempunyai hak yang sama memperoleh pendidikan Selain itu, Pendidikan ditujukan salah satunya untuk merubah cara pandang manusia agar menguasai kecakapan-kecakapan dalam hidup bermasyarakat. Sehingga, melalui pendidikan seseorang dapat terus belajar untuk menjadi semakin ahli dalam mengusai sebuah pengetahuan maupun ketrampilan.

Penguasaan pengetahuan maupun ketrampilan mutlak dimiliki oleh seseorang. Melalui pengetahuan yang cukup seseorang mampu untuk memberikan prediksi di masa yang akan datang. Dengan menguasai ketrampilan tertentu, seseorang juga mampu mengaplikasikan dan menuangkan prediksi atau pemikirannya dalam sebuah 
kreasi. Kreasi yang nantinya juga diharapkan dapat membantu berlangsungnya kehidupan yang lebih baik.

Namun, para pendidik seringkali melupakan aspek lain yang tidak kalah pentingnya dalam membentuk pemahaman dan penguasaan ketrampilan yakni sikap. Sikap seseorang dalam memproduksi pengetahuan dan ketrampilan sering diabaikan lantaran sifatnya yang inheren dengan pengetahuan dan ketrampilan itu sendiri. Padahal, sikap yang menjadi penggerak munculnya schema atau kerangka kognitif juga menjadi bagian penting untuk diperhatikan.

Sikap merupakan reaksi seseorang terhadap suatu kejadian di lingkungannya. Hal ini sejalan dengan pengertian sikap yang disampaikan oleh Khan \& Khan (2017: 209) yang menyatakan bahwa, "Atitudes are combination of beliefs and feelings that predisposes a person to behave a certain way.". Hal ini menerangkan bahwa, sikap merupakan kombinasi antara keyakinan dan perasaan yang mempengaruhi cara seseorang berprilaku.

Sikap merupakan reaksi awal yang mengendap dalam pikiran seseorang mengenai sesuatu. Reaksi awal inilah yang akan membangkitkan sebuah skemata (pemahaman awal) dan menjadikan pemahaman yang matang dalam struktur kognitif seseorang. Sehingga, sikap seseorang menjadi penting untuk diidentifikasi, diketahui, dan dikembangkan terutama sikap ilmiah dalam kegiatan pembelajaran.

Sikap ilmiah merupakan salah satu sikap yang penting untuk dikembangkan mulai dari pendidikan dasar sampai pada tingkat perguruan tinggi. Sikap ilmiah seringkali dituntut kemunculannya pada bidang kajian ilmu pengetahuan alam (IPA). Hal ini sesuai dengan salah satu fungsi pembelajaran IPA menurut Sumaji (Awang, 2012: 26) yaitu, "Menanamkan sikap ilmiah dan melatih siswa dalam menggunakan metode ilmiah untuk memecahkan masalah yang dihadapinya." Pernyataan ini dengan jelas memberikan arahan kepada guru IPA bahwa dalam mengajar IPA, sikap ilmiah siswa harus ditanamkan agar kelak mampu mengusai pengetahuan melalui metode ilmiah.

Sikap ilmiah adalah sikap-sikap yang harus dimiliki saat seseorang bekerja atau belajar dengan menggunakan metode ilmiah. Sikap ilmiah berada dalam pikiran seseorang yang akan mengevaluasi dan 
memastikan segala sesuatu terhadap lingkungannya. Hal ini sesuai dengan pernyataan Singh (Revati \& Meera, 2017: 63) yang menuliskan bahwa,"scientific attitude as a condition of mind, showing one is disposed towards certain things, ideas or person and the environment around." Hal ini berarti sikap ilmiah siswa adalah suatu kondisi yang memampukan siswa untuk memikirkan sebuah ide, gagasan tentang suatu objek dan sekelilingnya.

Pada pembelajaran IPA di sekolah dasar, sikap ilmiah diperlukan siswa untuk membantu memahami pengetahuan yang diterimanya. Hal ini sejalan dengan pendapat Awang (2013: 24) yang menyatakan bahwa,"Pembelajaran IPA di SD hendaknya membuka kesempatan untuk memupuk rasa ingin tahu peserta didik secara ilmiah." Rasa ingin tahu siswa membuat siswa tersebut akan mengekplorasi lebih jauh mengenai pengetahuan tersebut. Dengan demikian, sikap ilmiah menjadi energi penggerak siswa mendalami pengetahuan IPA.

Karakteristik mata pelajaran IPA yang mengharuskan siswa menguasai tidak hanya produk dan proses IPA, tetapi juga sikap (scientific attitude), membuat IPA menjadi bidang yang strategis untuk mengembangkan sikap ilmiah siswa. Barlia (Laksmi, et al 2013: 2) menuliskan, "IPA sebagai salah satu mata pelajaran pokok yang perlu dibina sedini mungkin pada jenjang Sekolah Dasar agar mampu melahirkan generasi muda yang memiliki sikap ilmiah yang lebih baik sehingga dapat membuat suatu keputusan, berwawasan masa depan, dan mampu memecahkan permasalahan yang dihadapi." Depdiknas pada tahun 2004 (Hendracipta, 2016: 110) menuliskan bahwa, dalam IPA terdapat tiga komponen yaitu, proses ilmiah, sikap ilmiah, dan hasil atau produk ilmiah. Pernyataan ini mendeskripsikan bahwa pada jenjang sekolah dasar adalah lebih baik ditanamkan sikap ilmiah sejak dini, sehingga mampu memecahkan persoalan di masa mendatang.

Sikap ilmiah atau scientific attitude dalam pembelajaran IPA meliputi sikapsikap a) rasa ingin tahu terhadap dunia fisik dan biologis serta cara kerjanya; b) memiliki rasa antusisme untuk menguasai pengetahuan dan metode sains; c) pengakuan bahwa sains dapat membantu pemecahan masalah-masalah individu dan global; d) pengakuan pentingnya pemahaman keilmuan dalam dunia masa kini; e) pengakuan bahwa sains 
merupakan aktiviatas manusia; f) pemahaman hubungan antara sains dan bentuk aktivitas manusia lainnya (Banawi, 2009: 53). Sikap-sikap ini sangat baik diterapkan dalam pembelajaran IPA.

Selanjutnya sikap ilmiah yang dimaksud oleh National Curriculum Council (Bundu, 2006) adalah sikap yang sangat penting dimiliki pada tingkatan pendidikan Sains adalah hasrat ingin tahu, menghargai kenyataan, sikap kritis, sikap hati-hati, tekun, ulet, tabah, kreatif untuk penemuan baru, berfikiran terbuka, dan bekerjasama dengan orang lain. Sikap ini tidak berbeda dengan yang disampaikan Harlen (Osman et al, 2007: 43) yang menuliskan,"... sikap saintifik tertentu seperti ingin tahu (curiosity), jujur dan tepat dalam merekodkan dan mengesahkan data (respect for evidence), berfikiran terbuka (willingness to change ideas) dan berfikiran kritikal (critical reflection)."

Kenyataan di SD Negeri 5 Sintang, memperlihatkan bahwa, siswa belum mampu menunjukkan sikap ilmiah pada saat pembelajaran sains. Siswa cenderung mengikuti arahan guru yang masih mempertahankan pembelajaran dengan ekspositori. Pembelajaran IPA dengan pendekatan ekspositori tidak akan mampu menumbuhkan sikap ilmiah siswa terhadap gejala sains. Sehingga diperlukan usaha dalam pelaksanaan pembelajaran yang menumbuhkan dan meningkatakan sikap ilmiah siswa yakni dengan penerapan pembelajaran berorientasi pada taxonomy for science education.

Taxonomy for science education adalah sebuah acuan pembelajaran dalam pendidikan sains, yang mampu meningkatkan aktivitas pembelajaran IPA di kelas dan mengembangkan sikap positif terhadap mata pelajaran itu (Loucks-Horsley, et al. dalam Awang \& Andri, 2017b: 194). Taxonomy for science education meliputi lima ranah hasil belajar yakni Ranah I (Knowing and Understanding); Ranah II (Science Process Skills); Ranah III (Imagine and Creativity); Ranah IV (Attitude and Value); dan Ranah $\vee$ (Conection and Applying) (MacCormack dan Yager, dalam Prasetyo, 2014). Melalui pembelajaran ini, siswa diharapkan mampu memperlihatkan sikap-sikap ilmiah dalam pembelajaran IPA karena pada pembelajaran ini diterapkan dengan hands-on activity.

Berdasarkan paparan tersebut, maka dilakukan penelitian tindakan kelas untuk meningkatkan sikap ilmiah siswa 
pada mata pelajaran IPA di sekolah dasar. Tujuan dari penelitian ini adalah untuk mengetahui seberapa besar peningkatan sikap ilmiah siswa setelah diterapkan pembelajaran berorientasi pada taxonomy for science education.

\section{Metode}

Penelitian menggunakan penelitian tindakan kelas (PTK). Akib $d k k$. (Permatasari, 2017: 99) menuliskan bahwa,"PTK adalah penelitian yang dilakukan guru di kelasnya sendiri melalui refleksi diri dengan tujuan untuk memperbaiki kinerjanya sehinggahasil belajar siswa meningkat.." PTK dilaksanakan dalam dua siklus dengan empat tahapan tindakan pada setiap siklus. Keempat tahapan tersebut adalah perencanaan, pelaksanaan tindakan, pengamatan, dan refleksi.

Pada tahap perencanaan, kegiatan yang dilakukan adalah merancang rencana pembelajaran dengan menggunakan pembelajaran berorientasi pada taxonomy for science education. Persiapan lain yang dilakukan adalah merancang angket sikap ilmiah siswa yang memasukan empat indikator sikap ilmiah menurut Harlen yaitu rasa ingin tahu, jujur, terbuka dan berpikir kritis. Selanjutnya pada tahap pelaksanaan, dilakukan penerapan pembelajaran berorientasi pada taxonomy for science education. Dimana pada pelaksanaan pembelajaran siswa diarahkan untuk dapat menunjukkan kelima ranah pembelajaran sains yakni ranah I (Knowing and Understanding); ranah II (Science Process Skills); ranah III (Imagine and Creativity); ranah IV (Attitude and Value); dan ranah $\mathrm{V}$ (Conection and Applying). Adapun pelaksanaan pembelajaran dilakukan dengan pendekatan hands-on activity.

Pada tahap pengamatan, guru mengamati aktivitas siswa saat melaksanakan pembelajaran. Melalui lembar observasi aktivitas siswa, guru melakukan pengamatan apakah siswa dapat beraktivitas dengan baik sesuai dengan arahan dari guru. Tahap terakhir yakni tahap refleksi merupakan suatu tahapan dimana guru melakukan evaluasi terhadap proses dan hasil pembelajaran yang dilakukan. Pada setiap akhir siklus, siswa diminta untuk mengisi angket sikap ilmiah seperti yang sudah dirancang.

Siswa yang menjadi subjek penelitian ini adalah siswa kelas IV SD Negeri 5 Sintang. Jumlah siswa kelas IV adalah 32 orang siswa dengan perincian 16 siswa laki-laki dan 16 siswa perempuan. Data yang dikumpulkan 
dalam penelitian adalah data sikap ilmiah siswa pada akhir siklus I dan akhir siklus II. Dari data yang terkumpul kemudian akan dianalisis dengan statistik deskriptif, untuk mengetahui rerata sikap ilmiah siswa dan tingkat ketuntasannya.

\section{Hasil dan Pembahasan}

Hasil penelitian tindakan kelas dengan penerapan pembelajaran berorientasi pada taxonomy for science education yakni angket sikap ilmiah siswa pada siklus I dan angket sikap ilmiah siswa pada siklus II. Angket sikap ilmiah siswa kelas IV sekolah dasar dirancang berdasarkan empat indikator yang disampaikan oleh Harlen yakni rasa ingin tahu, jujur, terbuka dan berpikir kritis. Dari keempat indikator tersebut dijabarkan menjadi 10 pernyataan. Pernyataan yang disusun tersebut di bersifat pernyataan positif dengan lima skala penilaian yaitu sangat setuju (SS), setuju (S), ragu-ragu $(R)$, tidak setuju (TS), dan sangat tidak setuju (STS).

Angket sikap ilmiah siswa kemudian diberikan kepada siswa sebagai responden karena telah mengikuti pembelajaran. Pengisian angket sikap ilmiah siswa dilakukan pada akhir siklus I dan akhir siklus II. Siswa diminta untuk mengisi angket sesuai dengan sikap alamiah yang mereka alami berkenaan dengan sikap ilmiah.

Hasil angket sikap ilmiah siswa berdasarkan indikatornya dapat direkapitulasi seperti terlihat pada Tabel 1.

Tabel 1. Rekapitulasi Sikap IImiah Siswa Berdasarkan Indikator

\begin{tabular}{lcc}
\hline \multirow{2}{*}{ Aspek } & \multicolumn{2}{c}{ Skor } \\
\cline { 2 - 3 } & Siklus I & Siklus II \\
\hline Rasa ingin tahu & & \\
$\quad$ Rerata & 9,2 & 9,3 \\
$\quad$ Simp. baku & 0,60 & 0,79 \\
Jujur & & \\
$\quad$ Rerata & 13,6 & 14,4 \\
$\quad$ Simp. baku & 0,99 & 0,7 \\
Terbuka & & \\
$\quad$ Rerata & 8,3 & 9,5 \\
$\quad$ Simp. baku & 0,86 & 0,62 \\
Berpikir kritis & & \\
$\quad$ Rerata & 12,9 & 14,7 \\
$\quad$ Simp. baku & 1,35 & 0,50 \\
Keseluruhan Indikator & \\
$\quad$ Rerata & 44,12 & 48,12 \\
$\quad$ Simp. baku & 1,89 & 1,60 \\
\hline
\end{tabular}


Pembelajaran Berorientasi Taxonomy For Science Education...

Berdasarkan Tabel 1, dapat ilmiah yakni 44,12 yang apabila diketahui bahwa untuk setiap indikator dikonsultasikan dengan Tabel 2., maka sikap ilmiah siswa pada siklus I sikap ilmiah siswa pada siklus I menunjukkan kondisi yang cukup baik. Dimana rerata pada setiap indikator masing-masing adalah 9,2; 13,6; 8,3; dan berkategori baik. Hal ini dikarenakan sikap ilmiah siswa muncul setelah pembelajaran dilaksanakan.

12,9. Rerata dari keempat indikator sikap

Tabel 2. Kategori Skor Sikap Ilmiah Siswa

\begin{tabular}{cl}
\hline Interval skor & \multicolumn{1}{c}{ Kategori } \\
\hline$X>45$ & Sangat baik \\
$35<X \leq 45$ & Baik \\
$25<X \leq 35$ & Cukup baik \\
$15<X \leq 25$ & Kurang baik \\
$X \leq 15$ & Tidak baik \\
\hline
\end{tabular}

Pada siklus II terlihat rerata pada setiap indikator masing-masing adalah 9,3; 14,4; 9,5; dan 14,7. Rerata dari keempat indikator sikap ilmiah pada siklus II tersebut berada di atas 45. Ini artinya sikap ilmiah siswa berada pada kategori sangat baik. Secara deskriptif, terdapat peningkatan sikap ilmiah siswa pada siklus II.

Meningkatnya sikap ilmiah siswa pada siklus II menunjukkan keberhasilan pembelajaran yang berorientasi pada taxonomy for science education. Dimana fokus dari pembelajaran ini adalah mengajak siswa untuk terlibat secara langsung mengekplorasi pengetahuan. Keterlibatan siswa secara langsung membuat siswa mengalami pengalaman yang otentik, sehingga ia mampu merespon konsep-konsep pengetahuan yang diterimanya.

Respon atas konsep pengetahuan yang disajikan guru melalui pembelajaran berorientasi pada taxonomy for science education menjadi titik awal siswa dalam memproduksi skemata dalam struktur kognitifnya. Melalui pembelajaran dengan pendekatan keterlibatan siswa (hands-on activity) secara aktif, siswa mampu mengkonstruksi pengetahuannya secara aktif. Hal ini sejalan dengan pendapat Piaget (Awang, 2017a: 7) yang menuliskan bahwa," Murid-murid mengkonstruksi pengetahuan secara aktif dan tidak menerimanya begitu saja dari guru." 
Berdasarkan hasil perhitungan ketuntasan sikap ilmiah seperti terlihat secara statistik deskripstif, diperoleh data pada Gambar 1.

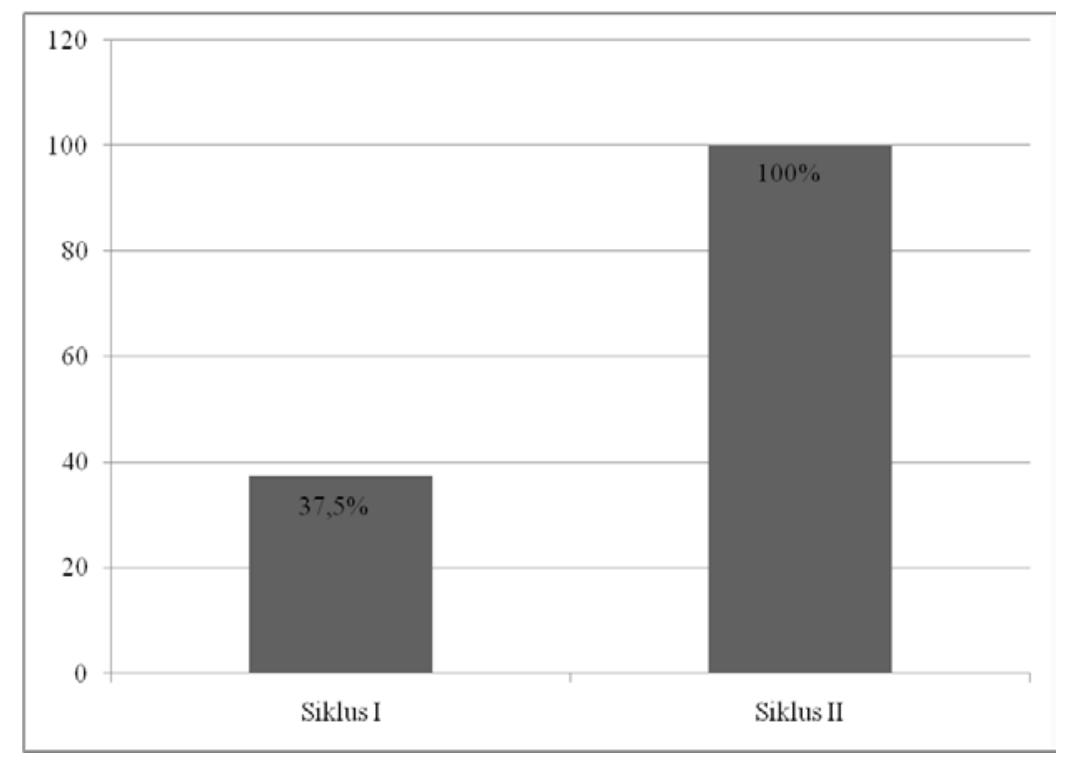

Gambar 1. Persentase Sikap Ilmiah Siswa pada siklus I dan Siklus II

Gambar 1 menunjukkan bahwa persentase sikap ilmiah siswa pada siklus I kurang dari $50 \%$ yakni hanya $37,5 \%$. Hal ini menunjukkan bahwa sikap ilmiah belum tertanam dalam diri siswa. Namun, hasil angket tersebut dapat dipandang sebagai sikap (ilmiah) awal siswa. Dimana, setiap anak mempunyai kemampuan merespon sesuai dengan tahap perkembangan mereka.

Setelah ditumbuhkembangkan melalui pembelajaran berorientasi pada taxonomy for science education, sikap ilmiah anak muncul dengan hasil yang luar biasa. Pada siklus II, persentase sikap ilmiah siswa berada pada angka
100\%. Hal ini membuktikan bahwa, apabila sikap ilmiah dikembangkan melalui sebuah pembelajaran, maka akan betumbuh dan berkembang dengan baik. Pembelajaran berorientasi pada taxonomy for science education, mengharuskan siswa menguasai lima ranah hasil belajar yakni ranah I (Knowing and Understanding); ranah II (Science Process Skills); ranah III (Imagine and Creativity); ranah IV (Attitude and Value); dan ranah $\mathrm{V}$ (Conection and Applying). Ranah I merupakan wilayah pengetahuan dan pemahaman. Mengacu pada hasil belajar ini, setelah melaksanakan kegiatan 
pembelajaran, siswa diharapkan mampu menguasai konsep yang diberikan guru. Selanjutnya ranah II yakni science process skills (ketrampilan proses sains), siswa diajak untuk melakukan kegiatan percobaan dan simulasi sehingga siswa mempunyai ketrampilan yang cukup dalam mengkontruksi pengetahuan. Pada wilyah ini, sikap ilmiah siswa muncul dengan sendirinya. Melalui kegiatan percobaan dan simulasi, siswa mampu menunjukkan sikap ilmiah demi mendukung penyelidikan konsep pengetahuaan yang diberikan guru.

Pada ranah III yakni imajinasi dan kreativitas, siswa semakin mendalami pekerjaan yang mereka lakukan. Pada wilayah ini, siswa diajak oleh guru untuk mampu memvisualisasikan konsep pengetahuan serta juga mampu menuangkan daya visualisasi mereka kedalam sebuah karya kreatif. Peran sikap ilmiah juga semakin dimunculkan. Karena bila tidak tumbuh sikap ilmiah, siswa tidak akan mampu melakukan aktivitas yang diminta oleh guru. Hal ini ditegaskan Myers (Sudana, dkk, 2010), yang menegaskan bahwa "Siswa mempunyai sikap yang lebih positif terhadap pembelajaran IPA". Selanjutnya pada ranah IV yakni attitude and value, siswa diajak untuk mampu menginternalisasi nilai-nilai yang terkandung dalam substansi materi dan proses pembelajaran melalui percobaan dan simulasi. Wilayah ini sangat erat hubungannya dengan penanaman sikap ilmiah. Karena nilai-nilai yang diperkenalkan bersinggungan dengan nilai-nilai yang terkandung dalam sikap ilmiah.

Kemudian pada ranah $\mathrm{V}$ yaitu connection and applying, siswa diminta untuk mampu melihat keluasan manfaat dari proses pembelajaran dan konsep pengetahuan yang diberikan. Sehingga secara umum,pengembangan sikap ilmiah siswa muncul secara terusmenerus dalam setiap proses pembelajaran.

Keberhasilan

pembelajaran berorientasi pada taxonomy for science education dalam meningkatkan sikap ilmiah siswa sejalan dengan penelitian sebelumnya. Awang (2017b: 278) menuliskan bahwa,"Pembelajaran berorientasi taxonomy for science education mempunyai pengaruh terhadap hasil belajar siswa". Hasil penelitian tersebut menjelaskan bahwa, pembelajaran berorientasi pada taxonomy for science education secara signifikan mempunyai pengaruh dalam merubah pemahaman konsep siswa. 
Perubahan pemahaman ini juga diawali dari bertumbuhnya sikap ilmiah siswa terhadap pengetahuan yang disampaikan guru.

Pengembangan sikap ilmiah
(scientific attitude) terutama pada
pembelajaran IImu Pengetahuan
(IPA) di sekolah dasar mutlak dilakukan. Penelitian." Pada anak usia awal, pembentukan konsep pengetahuan harus dilakukan dengan benar. Pembentukan konsep tersebut dipicu dengan menumbuhkembangkan sikap ilmiah pada diri anak. Seperti yang disampaikan Awang (2012: 26)," Tujuan pembelajaran tujuan dan fungsi pembelajaran IPA di SD selain memberi bekal pengetahuan, peserta didik juga diharapkan mempunyai sikap dalam menghargai IPA". Dengan demikian, peningkatan pemahaman siswa akan ilmu pengetahuan alam dapat ditumbuhkan secara benar melalui pengembangan sikap ilmiah anak.

Penelitian ini menunjukkan bahwa, melalui pembelajaran taxonomy for science education, sikap ilmiah siswa dapat dikembangkan. Kesadaran untuk mengembangkan sikap ilmiah siswa sejak dini melalui pembelajaran IPA dengan pendekatan hands-on activity akan menjadikan siswa dimasa mendatang mampu mengkonstruksi pengetahuan dengan baik.

\section{Simpulan dan Saran}

Berdasarkan hasil analisis data yang telah diakukan, diketahui bahwa rerata sikap ilmiah siswa pada siklus I yaitu 44,12 dan sikap ilmiah siswa pada siklus II yaitu 48,12. Tingkat ketuntasan sikap ilmiah siswa pada siklus I sebesar $37,5 \%$, meningkat sebesar 62,5\% menjadi 100\%. Dengan demikian, dapat disimpulkan terdapat peningkatan sikap ilmiah siswa setelah menggunakan pembelajaran berorietasi pada taxonomy for science education.

Dapun saran yang diberikan yaitu penelitian lanjutan dapat dilakukan pada subjek penelitian yang lebih luas agar diperoleh pengembangan teori pada pembelajaran dan variabel sikap ilmiah.

\section{Daftar Pustaka}

Awang, I.S., 2017a. Strategi pembelajaran, Tinjauan Umum Bagi pendidik. Sintang: STKIP Persada Khatulistiwa.

Awang, I.S., Andri. 2017b. Pengembangan Perangkat Pembelajaran IPA Berorientasi pada Taxonomy for Science Education di Sekolah Dasar. Jurnal Mimbar Sekolah Dasar 4 (3). 
Awang I.S. 2013. Keefektifan Model Pembelajaran Children Learning In Science (Clis) Pada Mata Pelajaran Ipa Ditinjau Dari Minat Dan Hasil Belajar Siswa Sekolah Dasar. Jurnal Vox Edukasi 4(2).

Awang, I.S. 2012. Pengembangan Subject SpesificPedagogy(SSP)Mata PelajaranIPA Untuk MengembangkanKarakterPeserta DidikKelasll Sekolah Dasar. Tesis magister, tidak diterbitkan, Universitas Negeri Yogyakarta, Yogyakarta. Tersedia http://eprints.uny.ac.id/8211/

Banawi, A. 2009. Keefektifan model pembelajaran IPA berbasis karakter dalam meningkatkan budi pekerti siswa sekolah dasar. Tesis magister, tidak diterbitkan, Yogyakarta: Universitas Negeri Yogyakarta.

Bundu, P. 2006. Penilaian keterampilan proses dan sikap ilmiah. Jakarta: Departemen Pendidikan Nasional Direktorat Jenderal Pendidikan Tinggi Direktorat Ketenagaan.

Hendracipta, N. 2016. Menumbuhkan Sikap IImiah Siswa Sekolah Dasar Melalui Pembelajaran IPA Berbasis Inkuiri. Jurnal Pendidikan Sekolah Dasar. 2(1).

Khan, M.A., Khan, F.S. 2017. Evaluating The Difference In Attitude Between Students And Illiterates Towards Disabled People. Journal Psychology Cognition 2 (4).

Laksmi, N.P.E.W., Parmiti, Dsk. P., Kusmariyatni, N. 2013. Pengaruh
Pendekatan Sains Teknologi Masyarakat Bermuatan Kearifan Lokal Tri Hita Karana Terhadap Sikap IImiah Siswa Kelas IV SD Negeri 1 Ubud. Jurnal Mimbar PGSD Undiksha 1 (1).

Osman, K., Iksan, Z.H., Halim, L. 2007. Sikap terhadap Sains dan Sikap Saintifik di kalangan Pelajar Sains. Jurnal Pendidikan 32 p.29-60. Tersedia

https://www.researchgate.net/publicati on/279479666_Sikap_terhadap_sains dan_sikap_saintifik_di_kalangan_pelaj ar_sains.

Permatasari, N.E. 2017. Pengaruh Penerapan Model Pembelajaran Picture And Picture dan Model Make A Match Terhadap Hasil Belajar Siswa. Jurnal Pendidikan Sekolah Dasar. 3(2).

Prasetyo, Z.K. 2014. Taksonomi untuk Pendidikan Fisika (Sains) Yogyakarta: Cakrawala Pendidikan Majalah IImiah Kependidikan. Edisi Khusus Dies, Mei 1998, 146-151.

Prihatiningsih, E., Setyanigtyas, E.W. 2018. Pengaruh Penerapan Model Pembelajaran Picture And Picture Dan Model Make A Match Terhadap Hasil Belajar Siswa. Jurnal Pendidikan Sekolah Dasar. 4(1).

Revati N, Meera, K.P. 2017. An Investigation of Scientific Attitude Among Secondary School Students In Kottayam District Of Kerala. IOSR Journal Of Research And Method In Education. 7(1) ver III. 